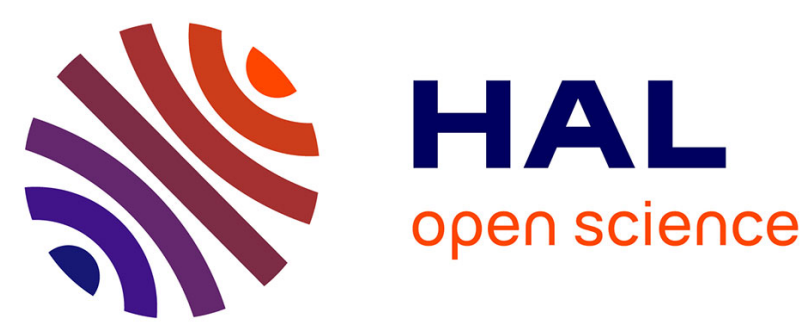

\title{
An Overview of Priority Pollutants in Selected Coal Mine Discharges in Europe
}

Philippe Gombert, Ondra Sracek, Nikolaos Koukouzas, Grzegorz Gzyl, Susana Tunon Valladares, Robert Fraczek, Christoph Klinger, Arkadiusz Bauerek, Juan Enrique Alvarez Areces, Sinead Chamberlain, et al.

\section{To cite this version:}

Philippe Gombert, Ondra Sracek, Nikolaos Koukouzas, Grzegorz Gzyl, Susana Tunon Valladares, et al. An Overview of Priority Pollutants in Selected Coal Mine Discharges in Europe. Mine Water and the Environment, 2019, 38 (1), pp.16-23. 10.1007/s10230-018-0547-8 . ineris-03319037

\section{HAL Id: ineris-03319037}

\section{https://hal-ineris.archives-ouvertes.fr/ineris-03319037}

Submitted on 11 Aug 2021

HAL is a multi-disciplinary open access archive for the deposit and dissemination of scientific research documents, whether they are published or not. The documents may come from teaching and research institutions in France or abroad, or from public or private research centers.
L'archive ouverte pluridisciplinaire HAL, est destinée au dépôt et à la diffusion de documents scientifiques de niveau recherche, publiés ou non, émanant des établissements d'enseignement et de recherche français ou étrangers, des laboratoires publics ou privés. 


\title{
An Overview of Priority Pollutants in Selected Coal Mine Discharges in Europe
}

\author{
Philippe Gombert ${ }^{*}$, Ondra Sracek ${ }^{2}$, Nikolaos Koukouzas ${ }^{3}$, Grzegorz Gzyl ${ }^{4}$, Susana Tuñon \\ Valladares $^{5}$, Robert Frączek ${ }^{6}$, Christoph Klinger ${ }^{7}$, Arkadiusz Bauerek ${ }^{4}$, Juan Enrique Álvarez \\ Areces ${ }^{8}$, Sinead Chamberlain?, Krzysztof Paw ${ }^{6}$, Lukasz Pierzchala ${ }^{4}$.
}

\author{
$1 *$ Corresponding author; INERIS, BP 2, 60550 Verneuil-en-Halatte, France, philippe.gombert@ineris.fr \\ ${ }^{2}$ Dept of Geology, Faculty of Science, Palacky University, 17. listopadu 12, 77146 Olomouc, Czech Republic \\ ${ }^{3}$ CERTH, 52, Egialias str. GR-15125 Maroussi-Athens, Greece \\ ${ }^{4}$ Central Mining Institute (GIG), Plac Gwarków, 40-166 Katowice, Poland \\ ${ }^{5}$ AMBERG Infraestructuras S.A., Avenida de la Industria, 37, 28108 Alcobendas, Madrid, Spain \\ ${ }^{6}$ TAURON, ZG Janina, Libiąż ul. Górnicza 23, Poland \\ ${ }^{7}$ DMT GmbH and Co. KG, Am Technologiepark 1, 45307 Essen, Germany \\ ${ }^{8}$ HUNOSA, Av. Galicia 44, 33005 Oviedo Asturias, Spain \\ ${ }^{9}$ The Coal Authority, 200 Lichfield Lane, Mansfield, Nottinghamshire, NG18 4RG, UK
}

\begin{abstract}
Coal mine water discharges in several European countries were investigated as part of the European Commission's MANAGER project. The emphasis of the project was identification of priority pollutants and potential remedial approaches. The main identified priority pollutants were sulphate (all countries) and iron (all countries except Greece). High concentrations of chloride (particularly in Germany and Poland) were associated with discharge of saline mine waters linked to the presence of fossil sea water; these mine waters also had high boron concentrations, in contrast to chloride-rich waters in UK that are linked to recent sea water inflow. Concentrations of trace metals vary among countries, but radium is an important contaminant in barium-rich waters with low sulphate concentrations, essentially in Poland. Concentrations of trace metals and metalloids were generally low because of their relative scarcity in coal strata and adsorption onto ferric oxides and hydroxides, but they still often exceeded the environmental quality thresholds.
\end{abstract}

Keywords: coal basin, pollution, database, emission limits.

\section{Introduction}

During coal mining, groundwater is pumped in order to lower the water table and permit exploitation. After abandonment and cessation of pumping, the natural rise of the water table inundates or floods the mined voids (Banks et al. 2010; Wolkersdorfer and Bowell 2004). This flooding, also called "rebound", can create a mine aquifer, as connections between the subsurface and surface waters, often used for drinking water, are reestablished (Younger et al. 2002). Also, during mining, the strata are exposed to an oxidizing environment, but the return to pre-mining water table levels restores low-oxygen conditions. Flushing of oxidized minerals can then release contaminants (Kopriva et al. 2005), which may pollute the local groundwater and surface waters (Gzyl and Banks 2007). Concentrations of dissolved major ions in untreated mine discharge are frequently very high (Cravotta 2008a; Cravotta and Brady 2015).

Contamination of mine water has been studied as part of the European MANAGER project, which was partly funded by the Research Fund for Coal and Steel (RFCS), to assess "Management of mine water discharges to mitigate environmental risks during the post-mining period". Mitigation of the environmental risks of mine water on aquatic ecosystems involves decreasing the discharge of contaminants. The main aim of the MANAGER project was to develop and implement cost-effective, sustainable, and innovative mine water treatment technologies to mitigate environmental risks after mine closure. This paper presents the results of the first part of the project, which focused on identifying mine water contaminants that cause the greatest environmental risks.

The main goals of this stage of the project were:

a) to gather information about mine water contaminants in various European coalfields in a coherent and comprehensive database;

b) to select mine water contaminants that pose risks to aquatic ecosystems, taking into consideration local conditions and the objectives of the Water Framework Directive. 
The study included numerous European coalfields from the 6 countries participating in the MANAGER project, i.e. France, Poland, Germany, Spain, Greece, and the United Kingdom (UK) (Fig. 1). A total of 97 representative coal mine waters were investigated and more than 26,000 analysis or physicochemical measurements were gathered.

\section{Figure 1 will be placed near here during the printing process}

\section{Review of Selected Coal Mine Waters in Europe}

\section{FRANCE}

INERIS, the French national institute for risk assessment, prepared a water composition database for the French coalfields, using data supplied by "Charbonnages de France" (the former French coal authority), GEODERIS (the French public interest group for risk management related to post-mining), INERIS files, and from scientific publications. The database contains 81 discharges with 450 flow measurements and 274 water analyses.

Coal mining began in France in the $13^{\text {th }}$ century and ended in 2004 (Bouzenot et al 2010). During this period, $4,700 \mathrm{Mt}$ of coal were extracted from nine major coal basins: most of them were in the Nord-Pas de Calais and the Lorraine basins, which respectively extend to Belgium and Germany. About half of all the French coal basins are now flooded and most of them discharge to surface waters. The main pollutants are sulphate and iron (Fabriol 2005).

The coal mine aquifers contain about $3 \times 10^{9} \mathrm{~m}^{3}$ of mine water and their total outflow is estimated to exceed 120 $\mathrm{Mm}^{3} / \mathrm{a}$, which is equivalent to about $6 \%$ of the total river flow in France. $95 \%$ of the coal mine waters flow into rivers, while $4 \%$ flows into lakes, and $1 \%$ flows directly into the sea.

\section{GERMANY}

Coal mining in Germany is very diverse, comprising both lignite and hard (anthracite and bituminous) coal. Whereas opencast lignite mining (not discussed in this paper) will continue post-2018, the last active hard coal mining will cease in 2018. The German hard coal measures extend east to west, following the Rhenohercynian and Saxothuringian strike, and extend into Belgium and France in the west and Poland in the east.

The remaining active mines can be found in the Ruhr Area (Rheinisch-Westfälisches Steinkohlerevier) and at Ibbenbüren. As in many other coal mining areas, the mines have varied hydraulic status; mines currently being flooded are located close to mines that have already been flooded and are discharging water. There is still no discharge during the flooding because pumping is temporarily being maintained. Furthermore, the groundwater level is not uniform; many abandoned and partially flooded mines in the Ruhr Area have a temporary water level below $-600 \mathrm{~m}$ b.s.l. This means that most of the German coal mines aquifers have not reached equilibrium conditions, which would allow for extrapolation of long term discharge flow rates and quality. Instead, an "unsaturated zone" exists above the mining water table, where oxidative reactions play an important role, and the potential for post-flooding mobilization of oxidation products is still considerable.

The Ruhr Area is the largest of the German coal fields and its discharges exceed the sum of all of the other German hard coal mining areas. Pumping rates in this area has ranged between 48 and $54 \mathrm{Mm}^{3} \cdot \mathrm{a}^{-1}$ during the last decade. However, its main environmental impact is related to the flow rate of the receiving water course. Therefore, future dewatering of the Ruhr Area plans within in frame of mine closure and cessation of pumping activities for withdrawal from some actual discharges into local rivers (Emscher, Ruhr, and Lippe), and installation of an underground drainage system via mining voids to a major discharge into the Rhine River, which can provide high dilution rates (Fischer 2015).

\section{GREECE}

Many coal basins exist in Greece: the major coal mining areas are found in or near Ptolemais, Florina, Drama, Elassona, Megalopolis, Ioannina, and Komnina (Koukouzas and Koukouzas 1995). Power generation in Greece relies mainly on lignite combustion (about $50 \%$ of power generation). The major generating stations are situated in Ptolemais-Kozani, Amyntaio, Florina, and Megalopoli, and are owned by the Public Power Corporation (PPC). Data concerning mine water discharges were obtained from the PPC Environmental Protection and Land Reclamation Sector Determination agency, and relate to the Ptolemais and Meliti opencast lignite mines. Water 
samples were collected and analysed from wells, pumping stations, and streams. The main contaminants were As, $\mathrm{Cd}, \mathrm{Cr}, \mathrm{Ni}, \mathrm{Zn}, \mathrm{Pb}, \mathrm{Hg}$, and $\mathrm{SO}_{4}$.

\section{POLAND}

Information on the impact of mine water discharges on the water environment in Poland is dispersed and not readily available. Under the framework of this project, multi-year data, including basic hydrochemical parameters, specific contaminants, and priority substances in 15 mine water discharges, were gathered by the Central Mining Institute in Katowice.

The Upper Silesian Coal Basin (USCB) is located in southern Poland and is one of the largest hard coal basins in the world (Rozkowski 1993). Hard coal has been mined in the USCB since about 1540. Recently (2014), there were 29 active hard coal mines, 25 abandoned coal mines still being dewatered, and one abandoned coal mine where dewatering has stopped and which consequently has been partially flooded. The amount of groundwater being pumped from the coal mines totals $209 \mathrm{Mm} / \mathrm{a}$. Mine dewatering is the main cause of the USCB's hydrochemical regime disturbances. Mine waters from these mines are typically discharged into tributaries of the upper Wisła (Vistula) and upper Odra (Oder) rivers (Janson et al. 2009). These mine waters are generally alkaline, but have elevated concentrations of sodium, chloride, and sulphate (Pluta and Zuber 1995). Radium is also often present in waters with low sulphate concentrations (Chalupnik and Wysocka 2008).

In the USCB, about 480 million metric tons of mine waste is stored in approximately 160 waste heaps (Szczepańska and Twardowska 1999; GUS 2015). Research carried out within the MANAGER project revealed that some of them may be considered to be "hot spots," releasing acidic runoff waters with high concentrations of sulphate, iron, aluminium, zinc, and nickel into the groundwater (Bauerek et al. 2014). Quantitative data concerning this phenomenon is sparse, although the data from the eastern part of Silesia shows that the environmental impact of contaminated runoff waters is locally important, and that it increases substantially during warmer periods of the year, when heavy rains occur (Bauerek et al. 2013). Some of the waste heap discharge waters are alkaline, but they frequently have high concentrations of sulphate, ammonia, and metals (Sracek et al. 2010).

\section{SPAIN}

In central Asturias, a large coal field has been mined since the early $19^{\text {th }}$ century in several exploitation units (Ojeda 1985). Most of the strata of the Central Carboniferous River basin can be considered effectively impermeable, except for some intensely fractured siliciclastic and carbonate rocks, through which infiltration takes place (Martos et al. 2008). There are more than 73 coal shafts in this area, and more than 300 mines and 2000 mine adits in this mountainous area (Fandos et al. 2004). Currently only four collieries remain in operation in two coal fields (San Nicolas and Santiago Colliery in the Caudal Field, and Maria Luisa and Carrio Colliery in the Nalón Field).

Coal has been mined in Spain for more than 200 years, generating a system called "anthropogenic aquifer," which is still being dewatered by several wells (Pendás and Loredo 2006). The low sulphur content in the coal, as well as the abundant carbonate materials, which act as a buffer, reduces the problem of acidic and ferruginous water. However, concentrations of sulphate, bicarbonate, calcium, magnesium, and other ions can be elevated (Martos et al. 2007). Hunosa, a state-owned coal company, is responsible for the mine water discharges at locations where pumping stations are installed. The total outflow exceeds $37 \mathrm{Mm}^{3} / \mathrm{a}$ for 15 discharge points, all of which are being monitored. In addition, four old mine water discharges have been periodically monitored.

\section{UNITED KINGDOM}

Underground and opencast mining is ongoing in the UK, but on a considerably reduced scale when compared with historic mining rates in the $19^{\text {th }}$ and $20^{\text {th }}$ centuries. The Coal Authority manages the effects of past coal mining, including mine water pollution, and has been regularly monitoring mine water levels and quality across the UK for over 20 years (Crooks and Thorn 2016). Most of the mine waters in the UK are circumneutral in $\mathrm{pH}$ and ferruginous, and range from fresh to hypersaline, depending on coal field geology, geometry, and mining history. Iron and, to a lesser extent, manganese are the principal metal contaminants in UK mine waters. Other metal and metalloid contaminants are typically only present at relatively low concentrations.

The Coal Authority operates 70 mine water treatment sites throughout Britain, of which 53 remediate existing mine water discharges and 17 treat water on-site to prevent new discharges of contaminated water (Lawrence 
2015). Together, the 70 mine water treatment sites prevent over 4,000 tons per year of iron from discharging into watercourses, and so improve and protect the UK's rivers and streams. Some water treatment operations also exist to protect important drinking water aquifers.

\section{Materials and Methods}

The first step for selecting priority substances for mine water was to develop a coherent and comprehensive methodology and the tools for gathering, storing, and analysing mine water contaminant data from different coalfields in Europe. This consisted of the following activities:

- Gathering available information, from all partners, about contaminants in rivers and mine water discharges from different coalfields in Europe, and collecting additional samples where data were lacking;

- Listing of 58 major and minor ions, metallic trace elements, and physicochemical parameters, based on all of the measured or analysed factors;

- assigning the following attributes to each discharge point:

$\circ$ individual name,

- information about geographical coordinates, country, coal district, name of mine, type of mining and mine status, and quantity and altitude of the discharges,

- name, code, and mile of river or water body where a discharge was localized.

- Standardization of units for each parameter (e.g. nitrogen compounds can be expressed in $\mathrm{mg}_{\mathrm{N}} / \mathrm{L}$ or $\mathrm{mg}_{\mathrm{NO} 3} / \mathrm{L}$, depending on the country);

- Replacement of concentrations under limits of detection (LOD) by systematically applying LOD/2; this was necessary because the studied countries had different LOD and/or the LOD may have varied over time;

- Performing a basic statistical evaluation based on multi-year observations for each mine water discharge point;

- Gathering information about emission limit values (ELV) and acceptable status ranges, according to local regulations introduced by the Water Framework Directive (WFD) as environmental quality standards (EQS).

The next step was to analyse the information gathered from the different coalfields to identify the important contaminants from the point of view of the WFD objectives. Water parameters that could cause environmental risks under specific local conditions, and contaminant concentrations in discharges that exceeded local pollutant emission limits, were also selected as mine water priority substances (MWPS). Selection of MWPS was based on two multi-year average contaminant concentrations (MACC) criteria, where a mine water discharge was causing a significant deterioration in water body status:

- The MACC of a specific contaminant in mine water discharges was exceeding an established ELV or EQS, based on local regulations or the WFD, regardless of initial water quality;

- The MACC of a specific contaminant in mine water discharges was not exceeding established ELV or EQS, but the water body quality exceeded one or more of these thresholds downstream of the mine water discharge point, based on local regulations or the WFD.

\section{Results and Discussion}

The main goals were achieved. A coherent and comprehensive database for storing and analysing mine water contaminant data from the different European coalfields was developed, and mine water priority substances that pose the risks to the aquatic ecosystems were identified. The database contains:

- Information about MACC at 97 mine water discharge points,

- ELV for 62 discharge points and EQS regarding the WFD,

- A list of mine water priority substances for each country, and

- Substantiation of the selected mine water priorities. 
Contaminants were identified that can cause environmental risks, such as deterioration of river ecosystems, when their concentrations exceed ELV for European coal mine waters (Table 1). Sulphate and iron were identified as priority substances in almost all of the countries, while several metallic and metalloid trace elements (e.g. As, Cr, $\mathrm{Zn}$ ) were problematic only in some. High concentrations of chloride (and sodium, not shown) were linked to the $\mathrm{Na}-\mathrm{Cl}$ brines associated with coal mining in Germany, Poland, and UK. High ${ }^{226} \mathrm{Ra}^{2+}$ concentrations in Germany and Poland were associated with high $\mathrm{Ba} / \mathrm{low}$ sulphate water.

\section{Table 1 will be placed near here during the printing process}

Box/whisker plots for the principal priority substances shown in Table 1 can be observed in Figure 2 . Concentrations values and basic statistical parameters are provided in Table 2. More than 26,000 analyses were gathered for 97 mines spread over the studied countries, ranging from 5 to 26 by country. These mines represent a total discharge of about $220 \mathrm{~m}^{3} / \mathrm{s}$, i.e. almost $7,000 \mathrm{Mm}^{3} / \mathrm{a}$.

\section{Figure 2 and Table 2 will be placed near here during the printing process}

The $\mathrm{pH}$ was always higher or equal to 6.0, with an average of 6.50 (Table 2). Sulphate (Fig. 2a) averaged 713 $\mathrm{mg} / \mathrm{L}$ and iron (Fig. 2b) averaged $20.9 \mathrm{mg} / \mathrm{L}$, for all of the country's mine discharges. These elements are produced by the oxidation of sulphides like pyrite (Blowes et al. 2003), which produces 1 mol of $\mathrm{Fe}^{2+}$ and 2 mol of $\mathrm{SO}_{4}{ }^{2-}$ for each mol of pyrite that is oxidized. The reaction also produces two mol of $\mathrm{H}^{+}$, which can react with carbonate rock, such as calcite and dolomite, if any is present in in the nearby strata.

Furthermore, the released $\mathrm{Fe}^{2+}$ is oxidized and precipitates at $\mathrm{pH}>3.0$ as ferric hydroxide, which is also an acidproducing reaction (Langmuir 1997). Meanwhile, the neutralization reactions can produce rather high concentrations of $\mathrm{Ca}^{2+}$ (Fig. 2a, Table 2), which in this study averaged $384 \mathrm{mg} \mathrm{L}^{-1}$, and $\mathrm{Mg}^{2+}$ (Fig. 2a), which averaged $169 \mathrm{mg} \mathrm{L}^{-1}$. The $\mathrm{Ca}^{2+}$ may precipitate with sulphate in neutralized waters as gypsum, $\mathrm{CaSO}_{4} \cdot 2 \mathrm{H}_{2} \mathrm{O}$, but sulphate in neutral $\mathrm{pH}$ mine waters generally behave in a conservative way because saturation with respect to gypsum is not typically reached. Jarosite, $\mathrm{KFe}_{3}\left(\mathrm{SO}_{4}\right)_{2}(\mathrm{OH})_{6}$, precipitates in mine waters at a $\mathrm{pH}<3.0$ (Langmuir 1997; Blowes et al. 2003) and, thus, cannot control sulphate concentrations in the generally circumneutral studied mine discharges.

Manganese was also present in most of the mine discharges (Fig. 2b), with an average value of $3.69 \mathrm{mg} / \mathrm{L}$.

Chloride together with sodium (not shown), averaged $2,747 \mathrm{mg} / \mathrm{L}$, and was most commonly associated with the coal deposits in Germany, Poland, and the UK (Fig. 2a). In Germany and Poland, these major ions come from fossil sea water but in the UK, they are probably due to sea water inflow into submarine mine adits (Younger et al. 2002). Chloride behaves conservatively in mine discharges and its concentrations generally decreases only by dilution and dispersion (Motyka and Postawa 2000). Boron (Fig. 2b), which averaged $0.96 \mathrm{mg} / \mathrm{L}$, is also linked to fossil sea water in Germany and Poland.

Lead (Fig. 2c) was present in all of the mine discharges except for Spain at relatively high concentrations (averaging $54.2 \mu \mathrm{g} / \mathrm{L}$ ), compared to its EQS $\left(1.2 \mu \mathrm{g} / \mathrm{L}^{-1}\right)$. Cadmium was also present in several of the mine discharges, presumably as a consequence of dissolution of carbonates. Its average concentration $(5.5 \mu \mathrm{g} / \mathrm{L}) \mathrm{was}$ also high relative to its EQS, which depends on water hardness; the EQS for Cd varies from less than $0.08 \mu \mathrm{g} / \mathrm{L}$ if the hardness $\left(\right.$ as $\mathrm{CaCO}_{3}$ ) is $<40 \mathrm{mg} / \mathrm{L}$ to $0.25 \mu \mathrm{g} / \mathrm{L}$ if the hardness exceeds $200 \mathrm{mg} / \mathrm{L}$. Typically, there is no solubility control on these contaminant concentrations but they can be attenuated by adsorption on ferric precipitates (Cravotta et al. 2008).

Significant concentrations of $\mathrm{Hg}$ (Fig. 2c) occur in coal mine discharges in several countries, averaging $0.3 \mu \mathrm{g} / \mathrm{L}$, which exceeds its EQS $(0.05 \mu \mathrm{g} / \mathrm{L})$, which means that many of the mine waters exceed this threshold.

High concentrations of Ni, As, and $\mathrm{Cr}$ (Fig. 2c) were less common and occur mostly in mine discharges in the UK, France, and Poland. Their respective average concentrations and EQS were $37.4 \mu \mathrm{g} / \mathrm{L}$ for Ni (EQS: $\left.4.0 \mu \mathrm{g} . \mathrm{L}^{-1}\right), 18.6 \mu \mathrm{g} / \mathrm{L}$ for As (EQS: $4.2 \mu \mathrm{g} / \mathrm{L}$ ), and $8.3 \mu \mathrm{g} / \mathrm{L}$ for Cr (EQS: $3.4 \mu \mathrm{g} / \mathrm{L}^{-1}$ ). Generally, there is no solubility control on the concentrations of these elements, but they also are adsorbed on precipitated ferric phases (reaction 3) at about neutral pH (Cravotta 2008b; Sracek et al. 2011) because desorption of oxyanions occurs at higher, alkaline $\mathrm{pH}$, i.e. for As at $\mathrm{pH}$ above 8.2 (Ravenscroft et al. 2009). These trace elements do not represent a global environmental problem for coal mine water. 
$\mathrm{Zn}$ was also found in mine water in Poland and Germany with sometimes very high concentrations (respective maxima at 17,800 and 25,000 $\mu \mathrm{g} / \mathrm{L}$ ), but there is no EQS for this element. Just like $\mathrm{Ni}, \mathrm{Zn}$ occurs as a cation and there is generally no solubility control on its concentrations in mine discharge.

Se can be an important issue in coal mine water (Vesper et al. 2008; Yudovich and Ketris 2006). However, it was only analysed in coal mine waters of Greece and Spain with an average concentration of $3.5 \mu \mathrm{g} / \mathrm{L}$. Again, there is no EQS for this element.

Finally, ${ }^{226} \mathrm{Ra}^{2+}$ (Fig. 2c), which averaged $1,190 \mu \mathrm{g} / \mathrm{L}$, is of particular interest, but it was present only in mine water discharges in Germany and Poland with significant differences (respective maxima were 7,300 and $244 \mu \mathrm{g} / \mathrm{L}$ ). In these waters, sulphate has been reduced by reactive organic matter (Appelo and Postma 2005) and so there is no solubility control of ${ }^{226} \mathrm{Ra}^{2+}$. In high sulphate waters, ${ }^{226} \mathrm{Ra}^{2+}$ co-precipitates with gypsum and/or barite (Chalupnik and Wysocka 2008). Relatively high concentrations of Ba (Fig. 2b), respectively averaging 26.1 and $5.1 \mathrm{mg} / \mathrm{L}$, also occur in low sulphate waters. High Ra and Ba concentrations in low sulphate waters are consistent with findings of Cravotta (2008b) coal mine discharges in Pennsylvania.

\section{Conclusions}

More than 26,000 mine water analyses were gathered from 97 mines from the countries involved in the project, i.e. France, Greece, Germany, Poland, Spain, and the UK. In each country, the amount of water stored in coal mine aquifers totals over $10^{9} \mathrm{~m}^{3}$, and the combined mine water outflow (natural in the case of abandoned mines or artificial, due to pumping, in the case of active mines) is around several hundred $\mathrm{Mm}^{3}$ per year. All the studied mines represent a total discharge of about $7,000 \mathrm{Mm}^{3} / \mathrm{a}$.

The quantitative influence of coal mine water discharges is therefore substantial, and evaluating their environmental impact on surface and underground water is important. The coal mine water quality evaluation notes a first group of pollutants, represented by $\mathrm{SO}_{4}$ and $\mathrm{Fe}$, which were shared by all countries; a second group of frequently observed pollutants $(\mathrm{Mn}, \mathrm{Cd}, \mathrm{Pb})$; and a third group, that is specific to certain mine waters $(\mathrm{Cl}, \mathrm{B}$, $\mathrm{Ba}, \mathrm{As}, \mathrm{Cr}, \mathrm{Ni}, \mathrm{Zn}, \mathrm{Hg}, \mathrm{Ra}$ ). Some discharges show substantial mineralization, frequently accompanied by high concentrations of metallic or metalloid trace elements, and sometimes by radium and barium, typically in low sulphate waters. Chloride and boron have a special status because they are linked to the impact of fossil sea water brines. The remaining trace metals generally were present at low concentrations, but since their EQS are very low, they often exceed these thresholds.

The selection of mine water priority substances was based on a comparison of river water quality standards with mine water quality data. This means that there is no certainty that the mine discharges of selected substances will cause deterioration of river status or adversely affect aquatic ecosystems. The mine water quality database that we developed identified the contaminants that are of primary concern from the point of view of achieving WFD objectives, and that should be considered during environmental risk assessment.

Acknowledgements: This paper was issued from the research project MANAGER (Management of mine water discharges to mitigate environmental risks for post-mining period). The authors thank the Research Fund for Coal and Steel (RFCS) of the European Commission for helping to fund this project (RFCR-CT-2013-00005).

\section{References}

Banks D, Frolik A, Gzyl G, Rogoz M (2010) Modeling and monitoring of mine water rebound in an abandoned coal mine complex: Siersza Mine, Upper Silesian Coal Basin, Poland, Hydrogeol J 18: 519-534

Bauerek A, Bebek M, Drobek L (2014) The concept of the pre-treatment of water runoff generated on mine waste pile of ZG Janina in Libiaz. Central Mining Institute, Katowice (unpubl)

Bauerek A, Bebek M, Sracek O, Smieja-Król B (2013) Chemical composition of surface runoff from flotation wastes of $\mathrm{Zn}-\mathrm{Pb}$ ore formation of the Mississippi Valley-type, Olkusz, southern Poland. J Geochem Explor 132: 54-62

Blowes DW, Ptacek CJ, Jambor JL, Weisener CG (2003) The geochemistry of acid mine drainage, In: Lollar BS (Ed), Environmental Geochemistry, Treatise on Geochemistry, Vol 9, Elsevier, Amsterdam (NL), pp 149204

Bouzenot P, Guise Y, Noirel JF, Prince M, Fabriol R, Foucher JL, Testard J, Vassal P, Goetz D, Ledoux E (2010) Post-mining in France. BRGM Publications, Geoscience Issues Collection, Orléans (F). 
Chalupnik S, Wysocka M (2008) Radium removal from mine waters in underground treatment installations. J Environ Radioactiv 99(10):1548-1552

Cravotta CA (2008a) Dissolved metals and associated constituents in abandoned coal-mine discharges, Pennsylvania, USA. Part 1: Constituent concentrations and correlations. Appl Geochem 23: 166-202

Cravotta CA (2008b) Dissolved metals and associated constituents in abandoned coal-mine discharges, Pennsylvania, USA. Part 2: Geochemical controls on constituent concentrations, Appl Geochem 23: 203226

Cravotta CAI, Brady KBC (2015) Priority pollutants and associated constituents in untreated and treated discharges from coal mining or processing facilities in Pennsylvania, USA, Appl Geochem 62: 109-130

Crooks J, Thorn P (2016) A sustainable approach to managing the treatment of mine waters associated with historic mining, in: Drebenstedt C, Paul M (Eds), Proc, IMWA 2016 - Mining Meets Water - Conflicts and Solutions. TU Bergakademie, Freiberg, pp 1303-1309

Fabriol R (2005) La gestion de l'eau des mines en phase post-extractive. Géosciences 2: 66-71

Fandos P, Rodríguez F, Gutiérrez AM, Álvarez JJ (2004) El yacimiento de HUNOSA en la Cuenca Carbonífera Central Asturiana. Informe inédito, Servicios de Geología del Caudal y del Nalón, Oviedo (ESP), 91 pp.

Fischer P (2015) Konzept zur langfristigen Optimierung der Grubenwasserhaltung im Ruhrrevier der RAG Aktiengesellschaft - Proc, Congress NACHBergbauzeit in NRW, Grubenwasserkonzept für das Ruhrrevier, TFH Georg Agricola, Bochum

GUS (2015) Ochrona środowiska. Warszawa, Główny Urząd Statystyczny (Environmental protection, Warsaw Central Statistical Office of Poland)

Gzyl G, Banks D (2007) Verification of the "first flush" phenomenon in mine water from coal mines in the Upper Silesian Coal Basin, Poland. J Contam Hydrol 92: 66-86

Janson E, Gzyl G, Banks D (2009) The occurrence and quality of mine water in the Upper Silesian Coal Basin, Poland. Mine Water Environ 28: 232-244

Kopřiva A, Zeman J, Sracek O (2005) High arsenic concentrations in mining waters at Kan`k, Czech Republic. In: Bundschuh J, Bhattacharya P, Chandrasekharam (eds), Natural Arsenic in Groundwater: Occurrence, Remediation and Management. AA Balkema Publ, Amsterdam, pp 49-56

Koukouzas C, Koukouzas N (1995) Coals of Greece: Distribution, Quality and Reserves. Geological Soc, London, Special Publication vol 82, pp $171-180$

Langmuir D (1997) Aqueous Environmental Geochemistry, Prentice Hall, (city of publication)

Lawrence PJ (2015) The Coal Authority annual report and accounts 2014-15, (city of publication)

Martos E, Álvarez CJ, Cordero C, Ordoñez A, Meléndez M, Garzón B, Loredo J (2007) Proc, XII Congreso Internacional de Energía y Recursos Minerales, Oviedo

Martos de la Torre E, Meléndez Asensio M, Fernández Mairlot I, Gaitto Piris M, Canto Toimil N, Cordero Escosura C, Álvarez Rodríguez C (2008) Mapa hidrogeológico del entorno minero Turón-Aller (Asturias, España). In: Investigación y gestión de los recursos del subsuelo. Libro homenaje al Profesor Fernando Pendás. Fernández JA, Loredo J, Fernández L, y Pernía JM (Eds), IGME, pp 631-645

Motyka J, Postawa A (2000) Influence of contaminated Vistula River water on the groundwater entering the Zakrzowek limestone quarry, Cracow region, Poland, Environ Earth Sci 39(3-4): 398-404

Ojeda G (1985) Asturias en la industrialización española, 1833-1907, Siglo XXI de España Editores, Madrid (ESP), $481 \mathrm{p}$.

Pendás, F. Loredo, J., 2006. El agua en los procesos de cierre de minas en Asturias. Proc. of Reunión CientíficoTécnica "Gestión del agua en los procesos de cierre de minas". ETS de Minas, Univ de Oviedo (ESP).

Pluta I, Zuber A (1995) Origin of brines in the Upper Silesian Coal Basin (Poland) inferred from stable isotope and chemical data, Appl Geochem 10: 447-460

Ravenscroft P, Brammer H, Richards K (2009). Arsenic Pollution. A Global Synthesis, Wiley-Blackwell, Hoboken (USA)

Rozkowski A (1993) Impact of mining on groundwater chemistry in the Upper Silesian Coal Basin (Poland). Mine Water Environ12: 95-106

Sracek O, Gzyl G, Frolik A, Kubica J, Bzowski Z, Gwozdziewicz M, Kura K (2010) Evaluation of the impacts of mine drainage from a coal waste pile on the surrounding environment at Smolnica, southern Poland, Environ Monitor Assess 165: 233-254

Sracek O, Filip J, Mihaljevič M, Kř́bek B, Majer V, Veselovský F (2011) Attenuation of dissolved metals in neutral mine drainage in the Zambian copper belt, Environ Monitor Assess 172: 287-299 
Szczepańska J, Twardowska I (1999) Distribution and environmental impact of coal-mining wastes in Upper Silesia, Poland. Environ Geol 38(3): 249-258.

Vesper DJ, Roy M, Rhoads CJ (2008) Selenium distribution and mode of occurrence in the Kanawha formation, southern West Virginia, USA. Int J Coal Geol73: 237-249

Wolkersdorfer C, Bowell R (2004) Contemporary reviews of mine water studies in Europe, Part 1, Mine Water Environ 23: 162-182

Younger PL, Banwart SA, Hedin RH (2002) Mine Water, Hydrology, Pollution, Remediation. Kluwer Academic Publ, Dordrecht (NL)

Yudovicvh YE, Ketris MP (2006) Selenium in coal: a review. Int J Coal Geol 67:112-126

\section{Figure Captions}

Fig. 1: Location of the studied coalfields in Europe: a) Major elements; b) Minor elements; c) Trace elements

Fig. 2: Concentrations of priority pollutants in mine waters; coloured boxes are the interval from the 1st quartile $(\mathrm{Q} 1)$ to the 3rd quartile $(\mathrm{Q} 3)$ and represent the median in the form of a horizontal black line; the vertical black bars correspond to the limits above which the values are considered abnormal, i.e. Q1 - 1.5 (Q3 - Q1) for the lower limit and Q3 + 1.5 (Q3 - Q1) for the upper limit. 
Table 1. Global statistics of priority pollutants. EQS (Environmental Quality Standards) are EQS-AA (Annual Average) for all trace elements but PNEC (predicted no effect concentrations) for As and $\mathrm{Cr}$ (under European Directive 2013/39/UE). No. = number of samples.

\begin{tabular}{|l|r|r|r|r|r|r|r|r|r|r|r|r|r|r|r|r|r|r|r|}
\hline & \multicolumn{3}{|c|}{ Major ions (mg/L) } & \multicolumn{1}{|c|}{ Minor ions (mg/L) } & \multicolumn{4}{|c|}{ Trace elements $(\mu \mathrm{g} / \mathrm{L})$} \\
\hline & $\mathrm{pH}$ & $\mathrm{Ca}$ & $\mathrm{Mg}$ & $\mathrm{Cl}$ & $\mathrm{SO}_{4}$ & $\mathrm{Fe}$ & $\mathrm{Mn}$ & $\mathrm{B}$ & $\mathrm{Ba}$ & $\mathrm{As}$ & $\mathrm{Cd}$ & $\mathrm{Cr}$ & $\mathrm{Pb}$ & $\mathrm{Ni}$ & $\mathrm{Zn}$ & $\mathrm{Hg}$ & $\mathrm{Se}$ & $\mathrm{Ra}$ \\
\hline No. & 2583 & 2470 & 2419 & 2972 & 2848 & 2538 & 2507 & 1977 & 1637 & 245 & 1269 & 846 & 1702 & 1758 & 1348 & 236 & 30 & 91 \\
\hline Min. & 6.0 & 1 & 1 & 1 & 0 & 0.01 & 0.01 & 0.01 & 0.01 & $\mathrm{bdl}$ & $\mathrm{bdl}$ & $\mathrm{bdl}$ & $\mathrm{bdl}$ & $\mathrm{bdl}$ & $\mathrm{bdl}$ & 0.1 & 0.3 & 0.01 \\
\hline Max. & 8.9 & 5070 & 1320 & 71400 & 4680 & 330 & 77.0 & 13.0 & 5800 & 900 & 130 & 155 & 2280 & 421 & 25000 & 2.5 & 10 & 7.30 \\
\hline Ave. & 6.5 & 384 & 169 & 2756 & 713 & 20.9 & 3.69 & 0.96 & 9.77 & 18.6 & 4.5 & 8.3 & 54.2 & 37.4 & 440 & 0.3 & 3.5 & 1.19 \\
\hline EQS & $6-9$ & & & & & & & & & 4.2 & $*$ & 3.4 & 1.2 & 4.0 & 7.8 & 0.05 & & \\
\hline
\end{tabular}

* depending on water hardness: from $<0.08 \mu \mathrm{g} / \mathrm{L}$ if hardness (as $\left.\mathrm{CaCO}_{3}\right)<40 \mathrm{mg} / \mathrm{L}$ to $0.25 \mu \mathrm{g} / \mathrm{L}$ if hardness $\geq 200 \mathrm{mg} / \mathrm{L}$; bdl

$=$ below detection limit

Table 2. Statistics of priority pollutants by country; Number (No.) represents the number of water samples analysed in the mines referenced in each country; "bdl" is below detection limit)

\begin{tabular}{|c|c|c|c|c|c|c|c|c|c|c|c|c|c|c|c|c|c|c|}
\hline \multirow{2}{*}{ Country } & & \multicolumn{4}{|c|}{ Major ions (mg/L) } & \multicolumn{4}{|c|}{ Minor ions $(\mathrm{mg} / \mathrm{L})$} & \multicolumn{8}{|c|}{ Trace elements $(\mu \mathrm{g} / \mathrm{L})$} & \multirow{2}{*}{$\begin{array}{c}\mathrm{Bq} / \mathrm{L} \\
\mathrm{Ra} \\
\end{array}$} \\
\hline & & $\mathrm{Ca}$ & $\mathrm{Mg}$ & $\mathrm{Cl}$ & $\mathrm{SO}_{4}$ & $\mathrm{Fe}$ & $\mathrm{Mn}$ & $\mathrm{B}$ & $\mathrm{Ba}$ & As & $\mathrm{Cd}$ & $\mathrm{Cr}$ & $\mathrm{Pb}$ & $\mathrm{Ni}$ & $\mathrm{Zn}$ & $\mathrm{Hg}$ & $\mathrm{Se}$ & \\
\hline \multirow{4}{*}{ Greece } & No. & 60 & 60 & 60 & 60 & 60 & 60 & 0 & 0 & 60 & 60 & 60 & 60 & 60 & 60 & 60 & 10 & 0 \\
\hline & Min. & 44 & 15 & 6 & 0 & 0.03 & 0.01 & & & 0.2 & 0.2 & 1.7 & 4.0 & 5.0 & 0.5 & bdl & 10.0 & \\
\hline & Max. & 184 & 49 & 78 & 467 & 1.21 & 0.10 & & & 3.2 & 1.3 & 28.0 & 12.0 & 24.0 & 40.0 & bdl & 10.0 & \\
\hline & Ave. & 94 & 28 & 16 & 144 & 0.18 & 0.03 & & & 1.1 & 1.0 & 3.9 & 5.1 & 8.7 & 6.8 & bdl & 10.0 & \\
\hline \multirow{4}{*}{ Spain } & No. & 67 & 67 & 0 & 65 & 65 & 63 & 40 & 0 & 40 & 40 & 40 & 40 & 40 & 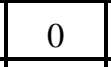 & 40 & 20 & 0 \\
\hline & Min. & 46 & 8 & & 24 & 0.01 & 0.01 & 0.01 & & \begin{tabular}{|l|}
0.3 \\
\end{tabular} & \begin{tabular}{|l|}
0.1 \\
\end{tabular} & \begin{tabular}{|l}
0.3 \\
\end{tabular} & 0.3 & bdl & & bdl & 0.3 & \\
\hline & Max. & 319 & 100 & & 1747 & 9.05 & 0.92 & \begin{tabular}{|l|}
0.19 \\
\end{tabular} & & \begin{tabular}{|l|}
9.4 \\
\end{tabular} & \begin{tabular}{|l|}
0.1 \\
\end{tabular} & \begin{tabular}{|l}
0.6 \\
\end{tabular} & 4.8 & 2.9 & & bdl & 0.4 & \\
\hline & Ave. & 129 & 53 & & 416 & 1.87 & 0.26 & 0.07 & & 0.6 & 0.1 & 0.3 & 0.4 & 1.4 & & bdl & 0.3 & \\
\hline \multirow{4}{*}{ Poland } & No. & 231 & 231 & 606 & 606 & 243 & 213 & 21 & 44 & 0 & 198 & 198 & 200 & 199 & 201 & 15 & 0 & 10 \\
\hline & Min. & 1 & 21 & 41 & 119 & 0.01 & 0.01 & 2.23 & 0.12 & bdl & bdl & 0.6 & 0.4 & 0.3 & 0.3 & 0.1 & & 0.060 \\
\hline & Max. & 1062 & 707 & 36072 & 2868 & 39.0 & 8.27 & 4.25 & 7.70 & bdl & 130 & 155 & 560 & 421 & 17800 & 2.5 & & 0.244 \\
\hline & Ave. & 263 & 162 & 7579 & 783 & 3.59 & 1.30 & 3.19 & 5.06 & bdl & 9.3 & 18.9 & 60.8 & 43.3 & 287 & 2.3 & & 0.160 \\
\hline \multirow{4}{*}{$\begin{array}{l}\text { United } \\
\text { Kingdo } \\
\mathrm{m}\end{array}$} & No. & 1427 & 1378 & 1427 & 1225 & 1313 & 1427 & 1340 & 986 & 53 & 385 & 0 & 848 & 900 & 484 & 0 & 0 & 0 \\
\hline & Min. & 1 & 1 & 6 & 3 & bdl & 0.03 & 0.01 & 0.01 & 1.0 & 0.3 & bdl & 1.0 & 10.0 & 5.0 & & & \\
\hline & Max. & 1920 & 1180 & 29100 & 4680 & 91.5 & 77.0 & 7.36 & 0.06 & 900 & 2.6 & \begin{tabular}{|l|} 
bdl \\
\end{tabular} & 2280 & 260 & 7840 & & & \\
\hline & \begin{tabular}{|l|} 
Ave. \\
\end{tabular} & 247 & 129 & 2296 & 944 & 34.2 & 5.58 & 0.73 & 0.03 & 21.9 & \begin{tabular}{|l|}
7.3 \\
\end{tabular} & bdl & 85.5 & 53.1 & 40.4 & & & \\
\hline \multirow{4}{*}{$\begin{array}{l}\text { German } \\
\mathrm{y}\end{array}$} & No. & 601 & 601 & 795 & 792 & 758 & 650 & 571 & 604 & 41 & 557 & 522 & 531 & 531 & 572 & 104 & 0 & 81 \\
\hline & Min. & 3 & 7 & 61 & 3 & \begin{tabular}{|l|}
0.01 \\
\end{tabular} & \begin{tabular}{|l|}
0.01 \\
\end{tabular} & 0.23 & 0.03 & 1.0 & 0.1 & 2.0 & 0.5 & 2.5 & 5.0 & 0.1 & & 0.010 \\
\hline & Max. & 5070 & 1320 & 70400 & 1890 & 330 & 28.0 & 13.0 & 580 & 10.0 & 40.0 & 130 & 1000 & 240 & 25000 & 0.6 & & 7.30 \\
\hline & \begin{tabular}{|l|} 
Ave. \\
\end{tabular} & 841 & 291 & 12597 & 353 & \begin{tabular}{|l|}
7.97 \\
\end{tabular} & \begin{tabular}{|l|}
1.19 \\
\end{tabular} & 1.51 & 26.1 & 5.0 & \begin{tabular}{|l|}
1.7 \\
\end{tabular} & \begin{tabular}{|l}
5.3 \\
\end{tabular} & 13.7 & 16.0 & 899 & 0.2 & & 1.32 \\
\hline \multirow{4}{*}{ France } & No. & 84 & 82 & 84 & 100 & 99 & 94 & 5 & 3 & 51 & 29 & 26 & 23 & 28 & 31 & 17 & 0 & 0 \\
\hline & Min. & 30 & 3 & 1 & 159 & 0.05 & 0.02 & 0.18 & 0.06 & 2.5 & 0.3 & 0.3 & bdl & 1.9 & 0.2 & 0.1 & & \\
\hline & Max. & 472 & 453 & 278 & 3010 & 43.8 & 9.11 & 1.01 & 0.11 & 347 & 25.0 & 57.2 & 50.0 & 32.0 & 500 & 1.0 & & \\
\hline & Ave. & 195 & 156 & 64 & 839 & 10.5 & 2.50 & 0.52 & \begin{tabular}{|l|} 
\\
\end{tabular} & 60.5 & 4.2 & \begin{tabular}{|l|}
10.2 \\
\end{tabular} & 4.9 & 10.5 & 42.3 & 0.3 & & \\
\hline
\end{tabular}

bdl $=$ below detection limit 


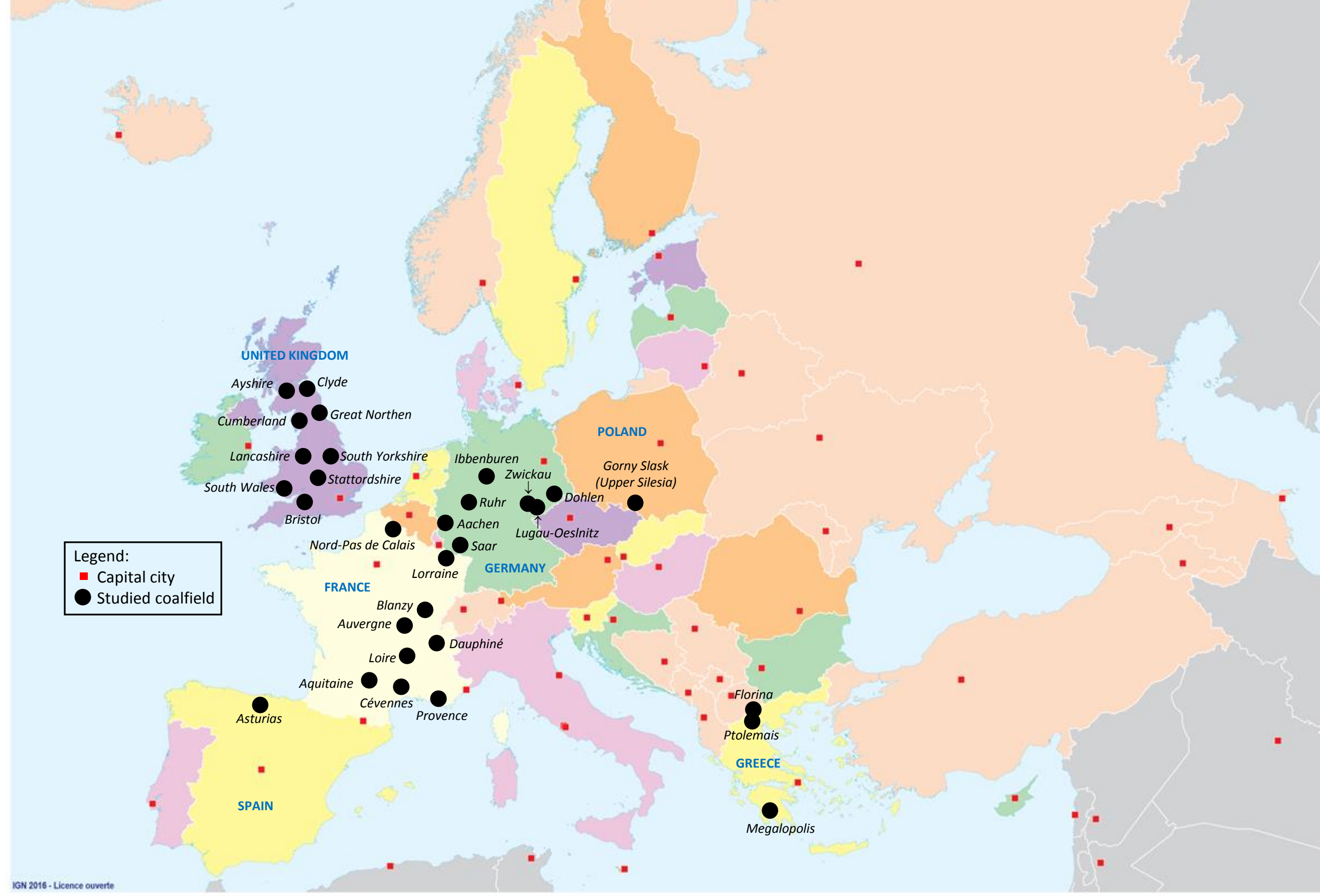


Fig $2 a$

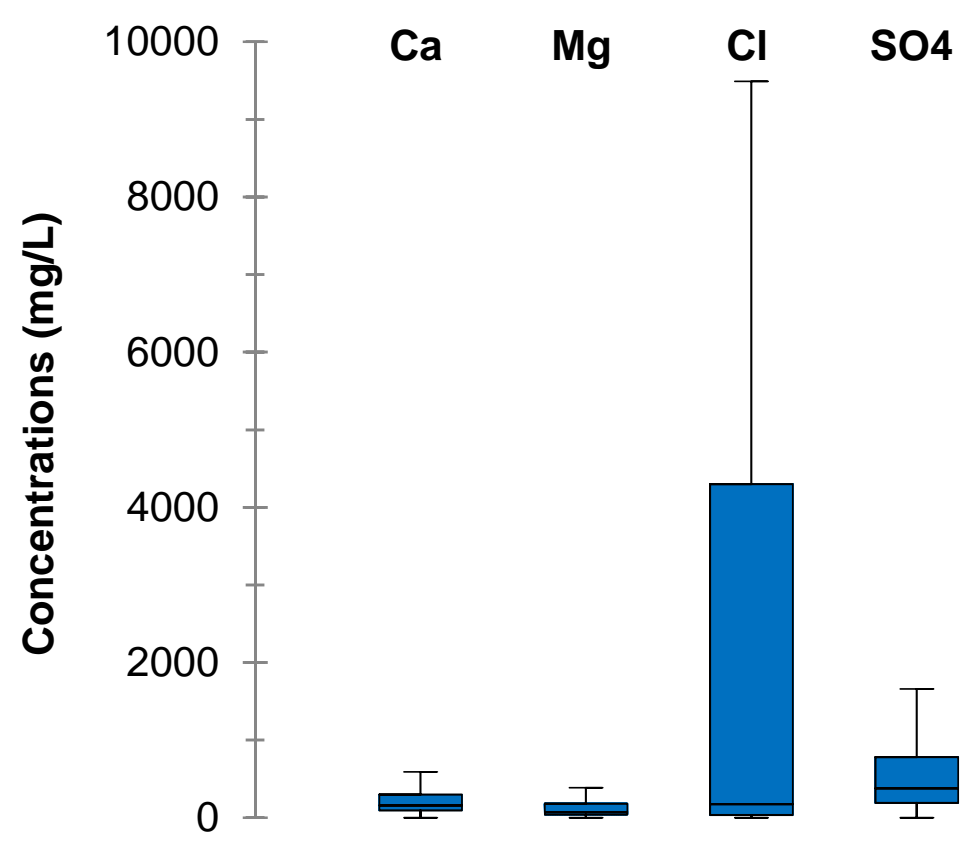


Fig $2 b$

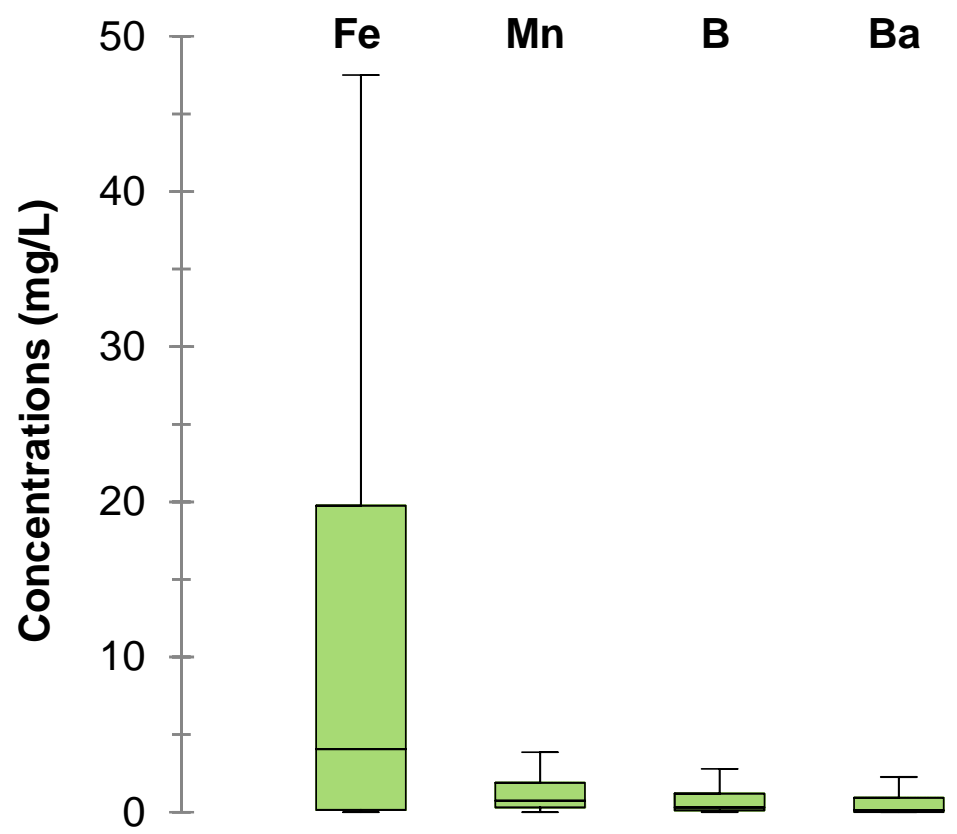


Fig 2c

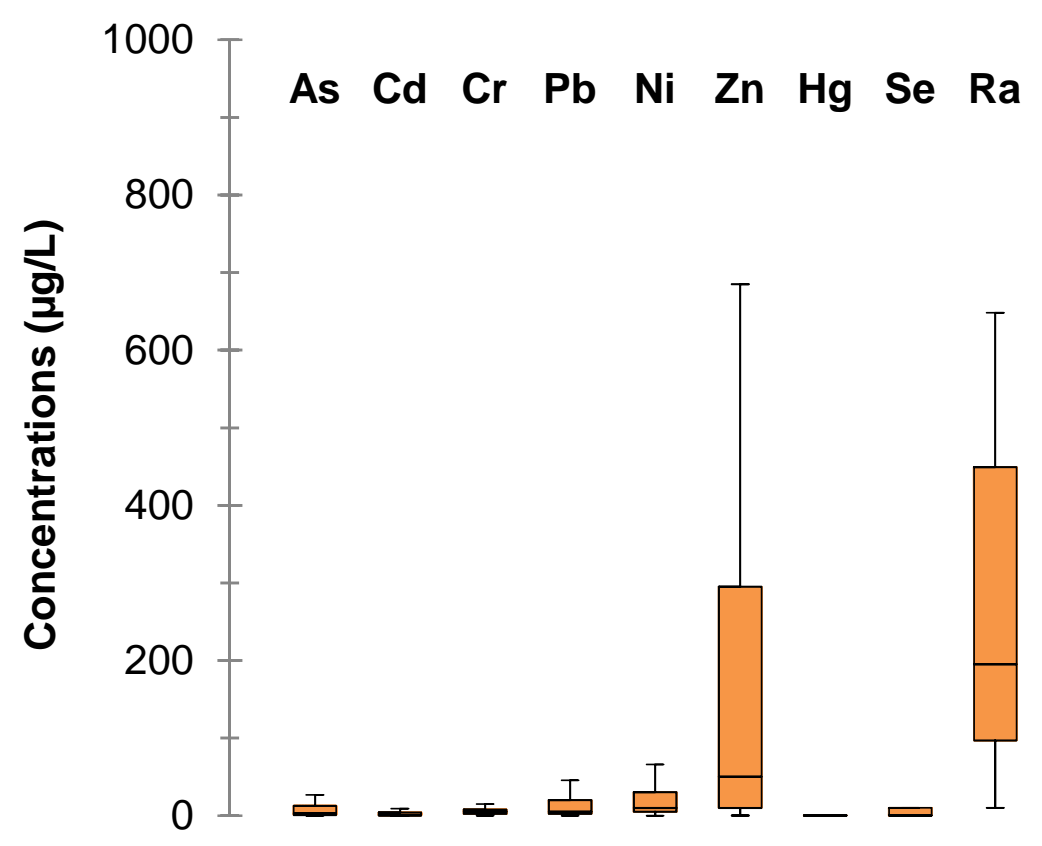

